Sport Science: Jurnal Sain Olahraga dan Pendidikan Jasmani ISSN 114-562X (Cetak), ISSN XXXX-XXXX(Online)

http://sportscience.ppj.unp.ac.id/index.php/jss/index

\title{
Hubungan Status Gizi Dengan Hasil Belajar Pendidikan Jasmani Olahraga Kesehatan Siswa Sekolah Dasar 52 Kuranji Kota Padang
}

\author{
Erlinda $^{1}$, Hendri Irawadi ${ }^{2}$, Edwarsyah $^{3}$ \\ ${ }^{123}$ Fakultas Ilmu Keolahragaan, Universitas Negeri Padang, Indonesia.
}

E-mail: $\underline{\text { erlinda@yahoo.com }}{ }^{1}, \underline{\text { hendriirawadi@fik.unp.ac.id }}$, edwarsyah@fik.unp.ac.id ${ }^{3}$

\begin{abstract}
Abstrak
Permaslahan dalam penelitian ini adalah rendahnya hasil belajar penjasorkes dan ini kemungkinan adanya hubungan dengan status gizi siswa, karena dalam pembelajaran penjasorkes banyak yang cepat lelalah dan kurang semangat. Tujuan penelitian adalah untuk mengetahui apakah ada hubungan status gizi dengan hasil belajar penjasorkes siswa SD 52 Kuranji Kota Padang.

Jenis penelitian ini adalah korelasional, populasi dalam penelitian ini adalah siswa kelas IV, V dan VI yang berjumlah 149 orang terdiri dari orang siswa putra dan orang siswa putri. Tehnik pengambilan sampel adalah stratifield proposive random sampling, Sampel diambil sebesar $30 \%$ dari populasi, data berasal dari responden, pengambilan data dilakukan dengan dokumentasi dan pengukuran antropometri siswa untuk mendapatkan data status gizi, data dianalisis dengan produck moment Statistical Product and Service Solution (SPSS).

Dari hasil penelitian analisis korelasi diketahu terdapat hubungan yang berarti antara status gizi dengan hasil belajar penjasorkes di SD 52 Kuranji Kota Padang, diterima kebenaran secara empiris pada tingkat kepercayaan 0.05 , koefisien korelasi 0.662 berarti lebih besar $(>)$ dari $\mathrm{r}$ table 0.482 , sedangkan puteri koefisien korelasi 0.541 berarti lebih besar $(>)$ dari $r$ tabel 0.444
\end{abstract}

Kata Kunci: Status gizi dan Hasil Belajar

\begin{abstract}
Problems in this study are the low learning outcomes of Physical Education and this is likely to have a relationship with the nutritional status of students, because in Physical Education learning many are quick to handle and lack of enthusiasm. The purpose of this study was to determine whether there was a relationship between nutritional status and the learning outcomes of Physical Education students at SD 52 Kuranji, Padang.

This type of research is correlational, the population in this study were students in grades $I V$, $V$ and VI, amounting to 149 people consisting of male students and female students. The sampling technique is stratifield proposive random sampling, the sample is taken by $30 \%$ of the population, the data comes from respondents, the data collection is done by documentation and anthropometric measurements of students to get nutritional status data, the data are analyzed with the produck moment Statistical Product and Service Solution (SPSS) .

From the results of the correlation analysis research, it is known that there is a significant relationship between nutritional status and physical education learning outcomes in SD 52 Kuranji, Padang, empirically accepted at the 0.05 confidence level, a correlation coefficient of 0.662 means greater $(>)$ than $r$ table 0.482 , while the daughter coefficient correlation 0.541 means greater $(>)$ than $r$ table 0.444
\end{abstract}




\section{Keywords: Nutritional Status and Learning Outcomes PENDAHULUAN}

Tujuan pendidikan nasional tersebut maka di Sekolah Dasar yang merupakan bagian dari sistim pendidikan formal, melaksanakan kegiatan Pembelajaran dalam seperangkat mata pelajaran. Salah satu mata pelajaran dimaksud adalah mata pelajaran Pendidikan Jasmani Olahraga dan Kesehatan(Penjasorkes). Fokus pembelajaran pendidikan jasmani olahraga dan kesehatan (Penjasorkes) diatas, dapat dikatakan bahwa pengembangan aspek kebugaran dan keterampilan gerak dasar merupakan dua komponen utama dalam pelaksanaan pembelajaran.

Pembelajaran penjasorkes harus dapat memacu pertumbuhan dan perkembangan jasmani, mental emosional dan sosial yang selaras dalam upaya membentuk dan mengembangkan kemampuan dasar, menanamkan nilai sikap dan membiasakan hidup sehat dikalangan siswa, untk itu diperlukan kecukupan akan gizi yang sangat dibutuhkan oleh tubuh. Faktor gizi merupakan salah satu yang sangat penting dalam kehidupan, kecukupan akan gizi sangat diperlukan oleh tubuh.

Seseorang kecukupan gizinya terpenuhi maka status gizinya akan baik, begitu juga sebaliknya. Seseorang perlu makan untuk menjaga agar tubuhnya tetap melakukan segala aktivitas fisologisnya. Makanan berfungsi untuk menjamin setiap orang agar tetap hidup makanan yang kita makan setiap hari hendaklah mengandung zat-zat giz yang dibutuhkan oleh tubuh, seperti karbohidrat, lemak, protein, lemak, mineral dan vitamin. Tiap zat gizi yang kita makan mempunyai fungsi berbeda-beda.

Sunita (2005) mengungkapkan: bahwa fungsi makanan yang kita makan adalah untuk "menghasilkan energi, membangun dan memelihara jarinngan serta mengatur proses kehidupan". Status gizi pada seseorang sangat besar pengaruhnya terhadap kesehatan dan juga penampilan. Bagi siswa yang mempunyai status gizi baik maka akan dapat melakukan tugas belajar dengan baik dan penuh semangat tanpa merasa lelah, dengan demikian juga berpengaruh terhadap hasil belajar. Status gizi pada setiap orang berbeda-beda karena berhubungan dengan kecukupan gizi yang dikonsumsi setiap hari dan juga dipengaruhi oleh faktor umur dan juga jenis kelamin (Wirjatmadi, 1998).

Pengamatan penulis dalam bidang studi penjasorkes di SD 52 Kuranji Kota Padang masih ada

siswa yang mempunyai hasil belajar yang rendah dan tidak sesuai dengan apa yang diharapkan.

Diduga faktor - faktor yang menjadi penyebabnya adalah: gizi, kondisi lingkungan, pengetahuan orang

tua, latar belakang ekonomi, motivasi, dan tidak terlepas dari metode guru mengajar. Dalam

keseluruhan proses pendidikan di sekolah, kegiatan belajar merupakan kegiatan yang paling pokok. Ini berarti bahwa hasil pencapaian tujuan pendidikan banyak tergantung kepada bagaimana proses belajar yang dialami oleh siswa sebagai anak didik.

Hasil belajar merupakan tolak ukur yang dapat digunakan untuk menentukan tingkat keberhasilan siswa dalam memahami suatu materi pelajaran. Hasil belajar siswa itu dapat diperoleh dengan mengadakan Evaluasi, dimana evaluasi itu merupakan bagian dari kegiatan belajar mengajar. Seseorang dapat dikatakan berhasil dalam belajar apabila terjadi perubahan tingkah laku didalam dirinya, baik dalam bentuk pengetahuan dan ketermpilan maupun dalam bentuk sikap dan nilai positif.

Menurut Slamento (1995:2) belajar adalah suatu proses usaha yang dilakukan sesorang untuk memperoleh suatu perobahan tingkah laku yang baru secara keseluruhan, sebagai hasil pengalamannya sendiri dalam interaksi dengan lingkungannya. Bbelajar adalah suatu situasi stimulus bersama dengan ingatan mempengaruhi pola pikir siswa sedemikian rupa sehingga perbuatannya berubah dari waktu sebelum ia mengalami situasi itu waktu sesudah ia mengalami situasi.Perubahan yang terjadi dalam diri siswa banyak sekali, baik sifat maupun jenisnya karena itu sudah tentu setiap perubahan dalam diri seseorang merupakan perubahan dalam arti belajar. Perubahan yang terjadi dalam belajar akan menyebabkan perubahan yang berikutnya, perubahan ini disebut hasil belajar. 


\section{METODE}

Jenis penelitian ini adalah korelasional, yakni untuk melihat hubungan antara status gizi dengan hasil belajar penjasorkes pada siswa SD 52 Kuranji Kota Padang. Penellitian ini dilakukan di SD 52 Kuranji Kota Padang, dan dilaksanakan pada bulan Januari 2010. Populasi dalam penelitian ini adalah seluruh murid kelas IV, V dan VI , baik laki-laki maupun perempuan yang berjumlah 149 . untuk lebih jelasnya dapat dilihat pada tabel berikut:

\section{Tabel 2. Populasi Penelitian}

\begin{tabular}{c|cc|c}
\hline \multirow{2}{*}{ Kelas } & \multicolumn{2}{|c|}{ Jenis Kelamin } & \multirow{2}{*}{ Jumlah } \\
\cline { 2 - 3 } & Putera & Puteri & \\
\hline IV & 25 & 30 & 55 \\
V & 25 & 28 & 53 \\
VI & 20 & 21 & 41 \\
Jumlah & 70 & 79 & 149 \\
\hline
\end{tabular}

Sumber : Tata usaha SD 52 Kuranji Kota Padang

Mengingat banyaknya jumlah populasi dalam penelitian ini, maka diadakan penarikan sampel yang dianggap dapat mewakili populasi. Adapun teknik penarikan sampel yang dilakukan adalah purvosive stratified random sampling, Menurut pendapat Hadi (1993:321) "jika populasinya lebih dari 100 orang maka sampel yang diambil minimal $10-25 \%$ dari jumlah populasi. Berdasarkan pendapat di atas, maka jumlah sampel sebanyak 37 orang yang diambil sebanyak $25 \%$ dari jumlah populasi. Untuk lebih jelas dapat dilihat seperti tabel berikut ini:

Tabel 3. Sampel Penelitian

\begin{tabular}{|c|ccc|}
\hline \multirow{2}{*}{ Kelas } & \multicolumn{2}{|c|}{ Jenis Kelamin } & \multirow{2}{*}{ Jumlah } \\
\cline { 2 - 3 } & Putera & Puteri & \\
\hline IV & 6 & 8 & 14 \\
V & 6 & 7 & 13 \\
VI & 5 & 5 & 10 \\
Jumlah & 17 & 20 & 37 \\
\hline
\end{tabular}

Sesuai dengan tujuan yang ingin dicapai maka jenis data dalam penelitian ini adalah data primer dan data sekunder. Data primer yaitu data yang dapat dikumpulkan secara langsung oleh peneliti saat melakukan pengukuran status gizi, sedangkan data sekunder yaitu data hasil belajar penjasorkes yang diperoleh dari Nilai Rapor Siswa SD 52 Kuranji Kota Padang . Sumber data dalam penelitian ini adalah Siswa - siswi SD 52 Kuranji Kota Padang meliputi kelas IV, V dan VI yang diperoleh dari pihak Sekolah.

\section{Tehnik dan Alat Pengumpulan Data}

1. Status gizi

Penetuan status gizi yang dipakai adalah dengan cara antropometri standar Harvard yakni; pengukuran Berat badan dibandingkan dengan Tinggi badan atau $\frac{B B(\mathrm{~kg})}{T B(\mathrm{~cm})}$ hasil ini kemudian dibandingkan dengan tabel terlampir, dengan klasifikasi sebagai berikut:

$$
\begin{array}{ll}
>90 \% \text { baku } & =\text { Gizi baik (4) } \\
80-90 \% \text { baku } & =\text { Gizi Sedang (3) } \\
70-80 \% \text { baku } & =\text { Gizi kurang (2) } \\
<70 \% \text { baku } & =\text { Gizi buruk (1) } \\
\text { Sumber: Djiteng Roejito D (1989:73) }
\end{array}
$$

2. Hasil Belajar

Hasil belajar penjasorkes diperoleh disekolah dari hasil ujian penjasorkes semester JuliDesember 2009 yang didapat dari Nilai rapor siswa SD 52 Kuranji Kota Padang. Tenik analisis data 
yang digunakan dalam penelitian ini adalah menggunakan analisis korelasi product moment dengan bantuan program SPSS 13, yang bertujuan untuk melihat hubungan variabel bebas (X) terhadap variabel terikat $(\mathrm{Y})$ dimana $\mathrm{X}=$ status gizi dan $\mathrm{Y}=$ hasil belajar yaitu :

\section{HASIL DAN PEMBAHASAN \\ Hasil Penelitian}

Deskriptif data yang dilakukan dalam penelitian ini adalah untuk melihat karakteristik distribusi data variable Status Gizi (X) dan variable Hasil Belajar (Y) sebagai berikut:

\section{Status Gizi}

Dalam menentukan status gizi dalam penelitian ini dilakukan pengukuran tinggi badan dan berat badan, kemudian untuk menentukan status gizi digunakan standar Harvard. Dari hasil staus gizi tersebut diberi skor, skor tertinggi 4 dan skor terendah skor 1. dari kelompok data didapatkan rerata hitung $($ mean $)=3.17$, standar deviasi $=0.80$, nilai minimum $=2.00$ dan nilai maksimum $=$ 4.00 , sedangkan hasil belajar diperoleh rerata hitung (mean) $=6.70$, standar deviasi $=0.68$, nilai minimum $=6.00$ dan nilai maksimum $=8.00$. sedangkan penyebaran data dapa dilihat pada table berikut ini:

\section{Tabel 4. Distribusi Data Status Gizi Siswa Putera}

\begin{tabular}{|l|c|c|c|}
\hline Klasifikasi & Skor & Fa & fr \\
\hline Baik & 4 & 7 & 41.2 \\
Sedang & 3 & 6 & 35.3 \\
Kurang & 2 & 4 & 23.5 \\
Buruk & 1 & 0 & 0 \\
& Jumlah & 17 & 100 \\
\hline
\end{tabular}

Berdasarkan table di atas terlihat bahwa siswa yang mempunyai status gizi baik sebanyak 7 orang $(41.2 \%)$, status gizi sedang sebanyak 6 orang (35.3\%), status gizi kurang sebanyak 4 orang (23.5\%), sedangkan siswa yang memiliki status gizi buruk tidak ada $(0 \%)$. Sedangkan untuk puteri dari 20 siswa dari hasil analisis status gizi diperoleh rerata hitung (mean) $=3.00$, standar deviasi $=$ 0.725 , nilai minimum $=2.00$ dan nilai maksimum $=4.00$, sedangkan mengenai hasil belajar, diperoleh rerata hitung $($ mean $)=6.65$, standar deviasi $=0.70$, nilai minimum $=6.00$ dan nilai maksimum $=8.00$. untuk lebih jelasnya dapat dilihat seperti table berikut:

Tabel 5. Distribusi Data Status Gizi Siswa Puteri

\begin{tabular}{|l|ccc|}
\hline Klasifikasi & Skor & Fa & fr \\
\hline Baik & 4 & 5 & 25.0 \\
Sedang & 3 & 10 & 50.0 \\
Kurang & 2 & 5 & 25.0 \\
Buruk & 1 & 0 & 0 \\
\multicolumn{1}{|c|}{ Jumlah } & & 20 & 100 \\
\hline
\end{tabular}

Berdasarkan tabel di atas terlihat bahwa siswa yang mempunyai status gizi baik sebanyak 5 orang $(25 \%)$, status gizi sedang sebanyak 10 orang $(50 \%)$, status gizi kurang sebanyak 5 orang (25\%), sedangkan siswa yang memiliki status gizi buruk tidak ada $(0 \%)$.

\section{Hasil Belajar Penjasorkes}

Hasil belajar penjarorkes diambil dari nilai rapor siswa, dari nilai tersebut didapatkan nilai tertinggi delapan (8) dan terendah enam (6). Untuk lebih jelasnya dapat dilihat pada table berikut ini:

Tabel 6. Hasil Belajar Penjasorkes Putera

\begin{tabular}{|c|c|c|}
\hline Nilai & Fa & Fr \\
\hline 8 & 2 & 11.8 \\
7 & 8 & 47.1 \\
6 & 7 & 47.2 \\
Jumlah & 17 & 100 \\
\hline
\end{tabular}


Dari table 7 di atas, terlihat bahwa 2 orang (11.8\%) memiliki nilai 8 , sebanyak 8 orang $(47.1 \%)$ memiliki nilai 7 , dan nilai 6 sebanyak 7 orang $(47.2 \%)$.

Sedang siswa puteri mempunyai rentangan sama dengan siswa putera nilai tertinggi delapan (8) dan terendah enam (6). Untuk lebih jelasnya dapat dilihat pada table berikut ini:

\section{Tabel 7. Hasil Belajar Penjasorkes Puteri}

\begin{tabular}{|c|c|c|}
\hline Nilai & Fa & Fr \\
\hline 8 & 2 & 10.0 \\
7 & 9 & 45.0 \\
6 & 9 & 45.0 \\
Jumlah & 20 & 100 \\
\hline
\end{tabular}

Dari table 8 di atas, terlihat bahwa 2 orang (10.0\%) memiliki nilai 8 , sebanyak 9 orang (45\%) memiliki nilai 7, dan nilai 6 sebanyak 9 orang $(45 \%)$. Selelengkapnya deskripsi data penelitian stataus gizi dan hasil belajar penjasorkes dapat dilihat seperti pada lampiran. Uji normalitas variabel menggunakan Kolmogorov-Smirnov Test, menunjukkan bahwa data variabel status gizi putera mempunyai signifikan 0.210 , dan hasil belajar 0.201 yang berarti lebih besar dari 0.05 atau bertribusi normal. Untuk lebih jelasnya dapat dilihat table berikut:

Tabel 8. Descriptive Data Penelitian Siswa Puteri

\begin{tabular}{|ll|r|r|}
\hline \multirow{2}{*}{$\mathrm{N}$} & & Status gizi & hasil belajar \\
\cline { 3 - 4 } & & 17 & 17 \\
\hline \multirow{2}{*}{ Normal Parameters(a,b) } & Mean & 3.1765 & 6.7059 \\
& Std. Deviation & .80896 & .68599 \\
& Absolute & .257 & .260 \\
Most Extreme Differences & Positive & .175 & .260 \\
& Negative & -.257 & -.254 \\
Kolmogorov-Smirnov Z & & 1.061 & 1.072 \\
Asymp. Sig. (2-tailed) & & .210 & .201 \\
\hline
\end{tabular}

Sedangkan untuk puteri menunjukkan bahwa data variabel status gizi puteri mempunyai signifikan 0.164, dan hasil belajar 0.080 yang berarti lebih besar dari 0.05 atau bertribusi normal. Untuk lebih jelasnya dapat dilihat table berikut:

Tabel 9. Descriptive Data Penelitian Siswa Puteri

\begin{tabular}{|lc|c|c|}
\hline \multirow{2}{*}{$\mathrm{N}$} & & Status gizi & Hasil belajar \\
\cline { 3 - 4 } & & 20 & 20 \\
\hline \multirow{2}{*}{ Normal Parameters(a,b) } & Mean & 3.0000 & 6.6500 \\
& Std. Deviation & .72548 & .67082 \\
& Absolute & .250 & .284 \\
Most Extreme Differences & Positive & .250 & .284 \\
& Negative & -.250 & -.249 \\
Kolmogorov-Smirnov Z & & 1.118 & 1.269 \\
Asymp. Sig. (2-tailed) & & .164 & .080 \\
\hline
\end{tabular}

Berdasar kedua tabel di atas dapat disimpulkan bahwa variabel status gizi (X) dan hasil belajar (Y) putera dan puteri siswa SD 52 Kuranji Kota Padang berdistribusi normal.Untuk membuktikan apakah status gizi sebagai variabel bebas mempunyai hubungan signifikan terhadap hasil belajar variabel terikat, diperlukan serangkaian proses (analisis) data yang dapat dipertanggungjawabkan secara empiris. Sebagai realisasi pembuktian dimaksud, dapat dilihat dari hasil perhitungan menggunakan formulasi produck moment Pearson dengan bantuan kompter program SPSS sebagai berikut; 


Tabel. 10 Hubungan Status Gizi dengan Hasil Belajar Putera
\begin{tabular}{|clcc|}
\hline & & Status gizi & hasil belajar \\
\hline Status Gizi & Pearson Correlation & 1 & $.662(* *)$ \\
& Sig. (2-tailed) & & .004 \\
& $\mathrm{~N}$ & 17 & 17 \\
hasil belajar & Pearson Correlation & $.662(* *)$ & 1 \\
& Sig. (2-tailed) & .004 & \\
& $\mathrm{~N}$ & 17 & 17 \\
\hline
\end{tabular}

** Correlation is significant at the 0.05 level (2-tailed).

Berdasarkan tabel di atas, dapat diketahui bahwa hubungan status gizi dengan hasil belajar putera diperoleh harga koefisien korelasi 0.662 berarti lebih besar $(>)$ dari $r$ table 0.482 , maka status gizi dengan hasil belajar mempunyai hubungan yang berarti. Untuk melihat kuatnyanya hubungan kedua variabel ini dibuktikan dengan sig 0.004 lebih kecil dari 0.05 bearti mempunyai hubungan yang signifikan. Sedangkan untuk puteri berdasarkan hasil analisis dapat diketahui bahwa terdapat hubungan antara status gizi dengan hasil belajar, kuatnya hubungan tersebut dapat dilihat seperti tabel berikut:

Tabel. 11 Hubungan Status Gizi dengan Hasil Belajar Puteri

\begin{tabular}{|cc|c|c|}
\hline & & Status gizi & Hasil belajar \\
\hline Status gizi & Pearson Correlation & 1 & $.541\left(^{*}\right)$ \\
& Sig. (2-tailed) & & .014 \\
& $\mathrm{~N}$ & 20 & 20 \\
Hasil & Pearson Correlation & $.541\left(^{*}\right)$ & 1 \\
belajar & Sig. (2-tailed) & .014 & \\
& $\mathrm{~N}$ & 20 & 20 \\
\hline
\end{tabular}

* Correlation is significant at the 0.05 level (2-tailed).

Berdasarkan tabel di atas, dapat diketahui bahwa hubungan status gizi dengan hasil belajar putera diperoleh harga koefisien korelasi 0.541 berarti lebih besar $(>)$ dari $\mathrm{r}$ tabel 0.444 , maka status gizi dengan hasil belajar mempunyai hubungan yang berarti. Untuk melihat kuatnya hubungan kedua variabel ini dibuktikan dengan sig 0.014 lebih kecil dari 0.05 . apabila probabilitas $<0.05$. Dengan demikian hipotesis penelitian diterima, $\mathrm{H}_{0}$ ditolak dan hipotesis $\mathrm{H}_{1}$ diterima, berarti terdapat hubungan yang signifikan antara status gizi dengan hasil belajar siswa SD 52 Kuranji Kota Padang.

\section{Pembahasan}

Dalam penelitian ini digunakan sebagai variabel bebas (independent variabel) adalah status gizi sedangkan hasil belajar adalah variabel terikat (dependen variabel). Berdasarkan hasil penilaian status gizi dapat diketahui bahwa dari 17 orang siswa putera SD 52 Kuranji Kota Padang skor status gizi diperoleh standar deviasi $=0.80$, nilai minimum $=2.00$ dan nilai maksimum $=4.00$, dan rerata hitung $($ mean $)=3.17$, sedangkan hasil belajar diperoleh rerata hitung $($ mean $)=6.70$, standar deviasi $=$ 0.68 , nilai minimum $=6.00$ dan nilai maksimum $=8.00$.

Dari hasil analisis data berdasarkan pada tabel deskripsi data penelitian status gizi siswa putra SD 52 Kuranji Kota Padang secara keseluruhan dapat diklasifikasikan rata-rata tergolong sedang (3.17). Sedangkan untuk putri dari 20 siswa dari hasil analisis status gizi diperoleh standar deviasi $=$ 0.725 , nilai minimum $=2.00$ dan nilai maksimum $=4.00$, dan rerata hitung (mean) $=3.00$ (sedang).

Keadaan gizi pada anak sangat di pengaruhi oleh factor ekonomi orang tua, dengan ekonomi yang kurang mencukupi maka akan berpengaruh kepada daya beli untuk kebutuhan sehari-hari terutama kebutuhan gizi. Dengan demikian kebutuhan akan zat makanan yang mengandung zat gizi 
sangat diperlukan untuk mendapatkan energi yang cukup dan seimbang bagi tubuh, karena siswa Sekolah Dasar merupakan usia yang sangat memerlukan gizi yang cukup untuk pertumbuhan.

Status Gizi merupakan ekspresi satu aspek atau lebih dari nutriture seorang individu dalam suatu variabel (Hadi, 2003). Status gizi adalah ekspresi dari keadaan keseimbangan dalam bentuk variabel tertentu Dengan demikian dapat disimpulkan bahwa status gizi merupakan hasil akhir dari keseimbangan zat- zat gizi yang masuk kedalam tubuh. Dapat disimpulkan bahwa status gizi siswa SD 52 Kuranji Kota Padang memiliki hubungan yang erat dengan hasil belajar siswa dimana apabila status gizinya baik maka cendrung memiliki hasil belajar yang baik dan begitu juga sebaliknya apabila status gizinya kurang maka cendrung diiringi kurangnya hasil belajar. Kemungkinan besar penyebab permasalahan ini dipengaruhi oleh faktor - faktor lain, seperti : ekomo orang tua, pendidikan orange tua, lingkungan tempat tinggal, motivasai belajar siswa dan sarana dan prasarana belajar yang kurang lengkap.

Menurut Slamento (1995:2) belajar adalah suatu proses usaha yang dilakukan seseorang untuk memperoleh suatu perubahan tingkah laku yang baru secara keseluruhan sebagai hasil pengalamannya sendiri dalam interaksi dengan lingkungannya. Untuk dapat mencapai hasil belajar yang baik seseorang juga harus bisa menimbang baik dan buruk sesuatu hal yang dialami didalam lingkungannya.

Depdikbud (1993:6) keberhasilan belajar dipengaruhi oleh dua faktor, yaitu internal dan eksternal. Hal ini berarti tidak hanya faktor internal yang dapat mempengaruhi hasil belajar seseorang, tetapi faktor eksternal juga sangat berpengaruh pada keberhasilan belajar.

Faktor Internal yang dapat mempengaruhi hasil belajar seperti: 1.Status gizi yang tidak mendukung dapat menyebabkan kelelahan, letih , lesu dan malas sehingga proses belajar tidak berjalan dengan optimal, 2. Motivasi belajar juga menentukan keberhasilan proses belajar seseorang, karena tanpa adanya niat untuk mengikuti proses belajar mengajar akan sulit untuk menerima pelajaran yang diberikan.

Faktor Eksternal juga dapat mempengaruhi hasil belajar seseorang seperti: Kondisi lingkungan yang tidak stabil akan mengakibatkan minat belajar seseorang berkurang sehingga menjadi malas untuk belajar, latar belakang ekonomi yang lemah juga mempengaruhi hasil belajar karena dengan lemahnya perekonomian akan sulit mendapatkan sarana pendidikan, seperti buku-pelajaran baju, sepatu, tas dan juga pelajaran tambahan (les), dengan keadaan peralatan sekolah yang kurang layak pakai akan menyebabkan kurang percaya diri dan dapat menimbulkan rasa malas bagi siswa.

\section{KESIMPULAN}

Berdasarkan hasil penelitian tentang hubungan status gizi dengan hasil belajar siswa SD 52 Kuranji Kota Padang dapat diambil kesimpulan : a) Status gizi siswa putera dan puteri SD 52 Kuranji Kota Padang berdasarkan hasil analisis deskriptif dapat dikatakan tergolong sedang dengan skor ratarata 3. b) Hasil belajar siswa putera dan puteri SD 52 Kuranji Kota Padang yang diperoleh dari hasil analisis data deskriptif, diperoleh hasil rata-rata 6.65 ini masih kurang, ini berarti hasil belajar putera dan puteri perlu ditingkatkan kemungkinan penyebabnya berasal dari faktor lain seperti kuranngnya motivasi dalam belajar, kondisi lingkungan, sarana dan prasarana, metode belajar dan lain - lain. c)Terdapat hubungan yang berarti antara status gizi dan hasil belajar penjasorkes siswa putera dan puteri SD 52 Kuranji Kota Padang harga koefisien korelasi 0.662 berarti lebih besar $(>)$ dari $r$ table 0.482 , sedangkan puteri koefisien korelasi 0.541 berarti lebih besar $(>)$ dari $\mathrm{r}$ tabel 0.444 .

Selanjutnya peneliti mengemukakan beberapa saran kepada berbagai pihak seperti: a) Para guru - guru SD 52 Kuranji Kota Padang agar lebih meningkatkan mutu pendidikan agar lebih baik lagi terutama memberikan perhatian khusus pada siswa putra yang masih rendah hasil belajarnya. b) Kepada guru penjasorkes agar dapat memperhatikan keadaan gizi siswa pada pembelajaran 
penjasorkes. c) Kepada orang tua siswa diharapkan agar dapat meningkatkan status gizi anaknya dengan pemenuhan kebutuhan gizi setiap hari. e) Kepada siswa agar memperhatikan makanan yang dimakan setiap hari apakah bergizi atau tidak, dan f) Kepada kepala Sekolah agar dapat memperhatikan siswa yang mengalami kurang gizi dan memberikan bantuan bea siswa.

\section{DAFTAR RUJUKAN}

Depdiknas RI . Buku Laporan Hasil Belajar Siswa Sekolah Dasar.

Depdikbud 1993. Psikologi Pendidikan Jakarta Depdikbud

Depkes RI 1999. Direktorat Bina Gizi Masyarakat. Jakarta Depkes RI

Hadi, Sutrisno. 1993. Statistik Pendidikan. Jakarta Gramedia

Kuntaraf, dkk. 1999. Makanan Sehat Bandung : Indonesia Publising House

Purwanto 2003. psikologi Pendidikan, Bandung PT Remaja Rusda Karya Roberg, dkk 1978 Penuntun Ilmu Gizi Jakarta Gramedia

Slamento. 1995. Belajar dan Faktor-faktor yang Mempengaruhi Jakarta PT. Rineka Cipta

Sunita. 2005. Gizi Masyarakat. Jakarta. Gramedia

Supariasa, dkk. 2002. Penilaian Status Gizi. Jakarta: EGC

Sedia Oetama (1996). Ilmu Gizi. Jakarta: Dian Rakyat

UNP.(2007). Buku PanduanPenulisan Tugas Akhir/skripsi. Universitas Negeri

Padang. Padang : UNP.

Wedya, 1991 Pengaruh Gizi Terhadap Hasil Belajar Siswa, Padang FPTK IKIP Padang

Wirjatmadi, Bambang. 1998. Penilaian Status Gizi. IKM Unair: Surabaya 